much more than local importance. It has already afforded the magnetic staff of the Discovery a most valuable opportunity of comparing their instruments and practising their use in southern latitudes, of which they fully availed themselves, and when it comes to dealing with the magnetic data of the Antarctic expeditions, the Christchurch records should prove invaluable.

The public spirit and the appreciation of scientific aims shown by the New Zealand Government in providing the necessary funds for erecting and maintaining the observatory is of happy augury. It shows that war is not the only department in which the colony is anxious to come to the front.

Though hardly referred to in the "Report," mention may also be made of the fact that, prior to the erection of the observatory, Dr. Farr took magnetic observations with the instruments lent by the Royal Society at about I 50 stations scattered over New Zealand, about half in each of the two principal islands. This constitutes an important contribution to the complete magnetic survey of New Zealand, which Dr. Farr puts forward as part of the programme which he intends to prosecute as circum. stances allow. The objects which Dr. Farr has in view will meet with warm sympathy from all interested in the extension of our knowledge of terrestrial magnetism, and it is to be hoped that his efforts will meet with the continued support necessary for their complete realisation.

\section{Charles ChreE.}

\section{THE KEARTON SELBORNE. ${ }^{1}$}

GI

LBERT WHITE'S famous natural history classic has already seen something over eighty editions, and the appearance of yet another may be taken as a sure indication that its popularity shows no signs of waning. Indeed, in these days of "nature-teaching," it is quite likely to become, if possible, more widely read than ever, since there are few works in the English language better calculated to show the value of the intelligent use of the eyes or better suited to aid in the cultivation of the powers of observation. If anything could increase the popularity of one of the most popular books in the world, it would be the addition of illustrations of a modern type, faultless in execution and appropriate in subject. To furnish such pictures, no living artists, we venture to say, are better qualified than the Messrs. Kearton. Their success in this particular instance speaks, as usual, for itself; and we shall perhaps best serve the interests of both artists and publishers if we ask those of our readers who may be disposed to doubt our words to judge for themselves.

It should, however, be stated that this edition of White is a low-priced one, intended for the general public, and in no sense an édition de luxe. It is of small size and printed in small type, and most of the illustrations are therefore of necessity also on a rather microscopic scale. In the case of views of the village and the neighbouring country, such as that of old cottages on p. 88, this detracts but little, if at all, from their effectiveness; but it must be confessed that some of the photographs of bird-life, such as the one of an osprey and its nest on p. 78 , would have been improved had it been practicable to reproduce them on a somewhat larger scale.

In his introduction, the editor claims that the illustrations are in closer touch with the spirit of the author than any which have previously appeared, and this we can fully endorse. What, for instance, could better illustrate White's observations on the young cuckoo and its foster-parents than the exquisite photograph on

1 “"The Natural History of Selborne." By Gilbert White. With notes by R. Kearton and illustrations by $C$. and R. Kearton. Pp. xvi +294 (London: Cassell and Co., Ltd., 1902.) Price 6s. 6d.

NO. I 740 , voL. 67$]$ p. I 30 of a sedge-warbler watching one of these usurpers which has expelled the rightful occupants of the nest? Or what could be more appropriate to the author's account of the Selborne ring-ousels than the illustration (herewith reproduced) of these birds feeding their young?-an illustration actually taken in the Selborne country, which cost the Messrs. Kearton at least a week's watching to obtain. At the risk of being considered hypercritical, we cannot, however, refrain from mentioning that the photograph of swallows on a telegraph-wire (p. I39) is somewhat of an anachronism in an eighteenth.century work. Again, on p. 35, a figure of harvest-mice and their nest would have been much better than the one of common mice ; but perhaps to obtain the former was impossible even to a Kearton. We also think that a photograph of a fallow-buck with fully developed antlers should have replaced the one on p. 27 , in which these appendages are less than half-grown. In other respects, we have nothing but commendation to bestow on the illustrations, both as regards subject and execution.

Although brief, Mr. R. Kearton's notes are very much to the point, and give all the information required by ordinary readers in regard to modern emendations on White's zoological determinations. We note, however, that the editor has not seen fit to follow modern views in

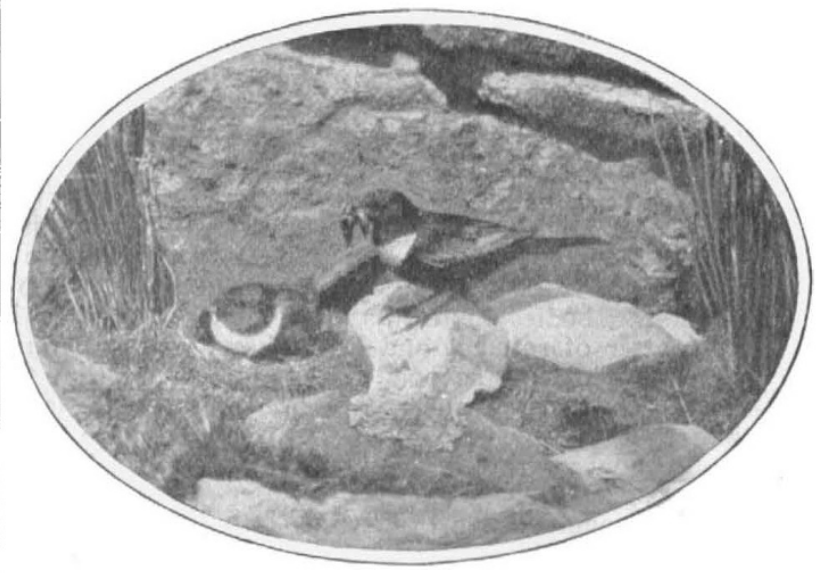

FIG. 1.-Ring-ousels eeding their young. From the Kearton "Selborne (Cassell and Co., Ltd.)

regard to the nomenclature of bats. The book appears singularly free from misprints (although we notice an unfortunate one on p. xiv.) and is admirably got up. It would be an insult to say that it is calculated to add to the Kearton reputation, since this is an impossibility, and we can do no more than commend it to the attention of all in search of an attractive gift-book.

R. L.

\section{RECENT CONFERENCES BETWEEN SCIENCE MASTERS AND EXAMINERS.}

DRING the past year or so signs have not been wanting that the unfortunate separation between teaching and examining, which has so often been deplored, is likely, before very long, to be either mended or ended. And we think that both the representatives of the Universities and the subcommittee of the Public School Science Masters' Association are to be congratulated on the new departures that were made at Cambridge on Saturday, February 7, and Oxford on Saturday, February I4, when they met at conferences summoned by the Vice-Chancellors of the respective Universities, to consider the question of entrance scholarships in the natural sciences given at the several 